\title{
Engineering Properties of Various Agricultural Residue
}

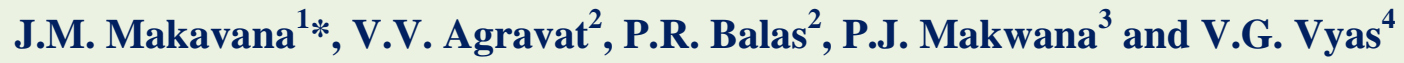 \\ ${ }^{1}$ Department of Renewable Energy Engineering, CAET, JAU, Junagadh, Gujarat, India \\ ${ }^{2}$ Department of Farm Power Engineering, CAET, JAU, Junagadh, Gujarat, India \\ ${ }^{3}$ Department of Soil and Water Engineering, CAET, JAU, Junagadh, India \\ ${ }^{4}$ Department of Food testing laboratory (biotechnology) JAU,Junagadh, Gujarat, India \\ *Corresponding author
}

\section{A B S T R A C T}

\section{Keywords}

Agricultural residue, Physical properties, Thermal properties

\section{Article Info}

Accepted:

20 May 2018

Available Online:

10 June 2018

\begin{abstract}
Various engineering properties of rice husk, rice straw, sugarcane bagasse and cotton stalk were estimated. Experiment was performed at SPRERI (Sardar Patel Renewable Energy Research Institute), Vallabh Vidyanagar, Gujarat. Different physical properties of these residues such as moisture content, bulk density, true density, porosity, angle of repose and thermal properties like volatile matter, ash content and fixed carbon was measured. Bulk density of rice husk and rice straw was $331.59 \mathrm{~kg} / \mathrm{m}^{3}$ and $380.54 \mathrm{~kg} / \mathrm{m}^{3}$ respectively. For sugarcane bagasse and cotton stalk it was 723.2 and $206.14 \mathrm{~kg} / \mathrm{m}^{3}$ respectively. Volatile matter and ash content for rice husk, rice straw, sugarcane bagasse and cotton stalk was recorded as 70.70, 64.43, 86.15,96.07 \% d.b. and 18.60, 15.20, 3.28, $6.93 \%$ d.b. respectively. Fixed carbon for rice husk, rice straw, sugarcane bagasse and cotton stalk was calculated as 10.7, 20.37, 10.62 and 10.7 respectively. These various engineering properties helps significantly for designing of equipment, enhance plant production, developing new technologies in which agricultural residues are used as raw material.
\end{abstract}

\section{Introduction}

Non-renewable resources have used frequently in India due to lack of awareness and acceptability of renewable energy sources by power consumer. There are many disadvantage of using nonrenewable energy resources as they have limited existence in environment, non-ecofriendly and not economical as India import all these type of energy resources. Therefore it is essential to explore many others sustainable energy sources. One of those non-conventional sources is biomass energy which can provide firm power of grid quality. Biomass is a renewable source of energy contains complex mix of carbon, nitrogen, hydrogen and oxygen. Biomass of this content is obtained from living or dead plants, by product of crop production, wood and agro based industry (Ravindranath, 1995).

India has huge amount of agriculture land area, so massive residues are produced here. These residue contents the potential of biomass feedstock for the use of energy generation (Prasad et al., 2007). All the organic materials produced as the by-product from harvesting of agricultural crop are termed as agricultural residue. More than 500 
million tons (Mt) of agricultural residues are produced every year and the average higher heating value (HHV) of Indian agricultural residue is $17.2 \mathrm{MJ} / \mathrm{kg}$ and the total power generation potential from these surplus residues is estimated at $23,237.8 \mathrm{MW}$ (MNRE, 2009; IARI, 2012). Residue which is obtained in the field at the time of yield are field based or primary residue, whereas those are assembled during processing are defined as processing based or secondary residue (Murali et.al. 2007). Rice straw, sugar cane tops etc. are primary residue whereas rice husk and bagasse are example of secondary residue.

By finding various engineering properties for agricultural residues it becomes much easier to know that where it will be used particularly. Physical properties of a product helpsin designing the equipment to handle, transport, process, store the material and quality evaluation of products. Parlikar and Bhatawdekar (1987) reported its usefor preparation of microcrystalline cellulose. Production ofedible mushrooms on cotton stalks was reported by Balasubramanya, (1981). Shaikh and Sundaram (1988) reported a process for development of pulp and paper, and corrugated fibre board from cotton stalks. Use of cotton stalks as fuel was reported by Purohit et al., (2006). Production of boards from cotton stalks is reported to be cheaper than the conventional process as pulverization consumes much less power compared to hard woods. Efforts have been made to produce lightweight, fire proof, corrugated roofing material, similar to asbestos cement sheets (Sundaram et al., 1989).

It is quite usual to burn the crop residue in India. Now a days ithas become major problem which causes severe pollution of land and water on local as well as regional and global scales. It is estimated that burning of paddy straw results in annual nutrient losses of 3.85 million tonnes of organic carbon, 59,000 $\mathrm{t}$ of nitrogen, 20,000 $\mathrm{t}$ of phosphorus and $34,000 \mathrm{t}$ of potassium at the aggregate $(\mathrm{P}$ Kumar et al., 2015). The amount of available surplus crop residues is estimated between 84 and $141 \mathrm{Mt} / \mathrm{year}$ where cereals crops contribute $58 \%$. Of the $82 \mathrm{Mt}$ of surplus crop residues nearly 70 MTs (44.5 Mt rice straws and 24.5 Mt wheat straws) are burned annually (Y Singh et al., 2014). Burning of rice straw is common in north-western parts of India causing nutrient losses, and serious air quality problems affecting human health and safety.

The present study was planned to determine the different engineering properties of rice husk, rice straw, sugarcane bagasse and cotton stalk.

\section{Materials and Methods}

To determine engineering properties and proximate analysis of different agricultural residues of rice husk, rice straw, sugarcane bagasse and cotton stalk, methodology was adopted as under.

\section{Location and sample collection}

The experiment was conducted at SPRERI (Sardar Patel Renewable Energy Research Institute), Vallabh Vidyanagar, Gujarat, India. All the agricultural residues were collected fromthe farmers' field. Variety was selected as follows.

\begin{tabular}{|l|l|}
\hline Crop & Variety \\
\hline rice & Mahisagar \\
\hline sugarcane & 671 \\
\hline cotton & GADC-2 \\
\hline
\end{tabular}

\section{Sample preparation}

All these raw materials were first sun dried in an open area to minimize the moisture content. The size reduction was carried out manually. 
Hammer mill was used for further size reduction. After this stage material converts in coarse ground form. Specially, sample of sugarcane bagasse was then reground through a40-mesh sieve $(0.425 \mathrm{~mm})$.

Engineering properties like bulk density, true density, equivalent diameter and angle of repose were found as depicted below:

\section{Bulk density}

The bulk density of a material is defined as its mass per unit bulk volume. The bulk density of the cotton stalk was measured by measuring weight of known volume of sample (Aggarwal and Khanna, 2006). This same method was adopted for all the residues. Bulk density was found as follows.

$\rho=\frac{m}{V}$

Where,

$\rho=$ bulk density $\mathrm{g} / \mathrm{ml}$,

$\mathrm{m}=$ mass of material $(\mathrm{g})$,

$\mathrm{V}=$ bulk volume of that material $(\mathrm{ml})$

\section{True density and porosity}

True density was determined by kerosene oil displacement method. In this method, a known weight of sample was put into a graduated jar containing kerosene oil and volume displaced by it was noted (Bhattacharya et al., 1972). Porosity was calculated from the values of bulk density and true density using the relationship:

True density $=\frac{\text { Weight of sample,g }}{\text { Volume displaced,cc }}$

Porosity, $\%=\frac{\text { True density-Bulk density }}{\text { True density }} \times 100$

\section{Angle of repose}

The angle of repose was measured with the help of cylinder arrangement. The cylinder was filled up to the top with the sample and then slowly lifted, thus a conical shape of the material resulted by measuring the height of the cone (Stegner, 1972), angle of repose was determined as:

$\alpha=\tan ^{-1}(2 \mathrm{H} / \mathrm{B})$

Where,

$\alpha=$ Angle of repose in degrees

$\mathrm{H}=$ Height of cone

$\mathrm{B}=$ Base of the cone

\section{Proximate analysis}

A proximate analysis, as defined by ASTM, is the determination by prescribed methods of moisture, volatile matter, fixed carbon and ash.

\section{Moisture content}

The moisture content was determined by standard oven method (AOAC, 2000). Five g of sample was weighed and dried at $103 \pm 2{ }^{\circ} \mathrm{C}$ for $16 \mathrm{hrs}$ in uncovered pre-weighted petridishes. The moisture content was calculated, using the following relationship:

Moisture content, \% d.b. $=\frac{W 2-w 3}{W 2-W 1}$

Where,

$\mathrm{W} 1=$ initial weight of the sample $(\mathrm{g})$

$\mathrm{W} 2$ = final weight of the sample $(\mathrm{g})$

\section{Volatile matter}

Volatile matter of solid biomass is the product, exclusive of moisture, given off by a material as a gas or vapor when solid biomass is heated out of contact with air under standardized conditions that may vary according to the 
nature of the material. Oven-dried biomass sample is kept in the tarred crucible. Two drops of benzene is added init to displace air in the environment surrounding the sample. The crucible is closed with lid and placed in the muffle furnace and heated at $600 \pm 10{ }^{\circ} \mathrm{C}$ for six minutes and $900 \pm 10{ }^{\circ} \mathrm{C}$ for another six minutes. The loss in weight divided by the initial weight of biomass will give the volatile matter on dry basis in the fuel (ASTM E870$82,2013)$.

Volatile matter $(\%, \mathrm{~d} . \mathrm{b})=\frac{w 2-w 3}{w 2-w 1}$

Where,

$\mathrm{W}_{1}=$ Weight of the empty crucible $(\mathrm{g})$

$\mathrm{W}_{2}=$ Initial weight of the sample plus crucible (g)

$\mathrm{W}_{3}=$ Final weight of sample plus crucible $(\mathrm{g})$

\section{Ash content}

Fuels with high ash content impose slag/clinker formation problems. Ash content (AC) is expressed as the percentage of residue remaining after dry oxidation of biomass. In this method, oven-dried biomass sample kept in the silica crucible is placed in the muffle furnace at $575 \pm 25{ }^{\circ} \mathrm{C}$ till constant weight. The ratio of the final weight to the initial weight of the sample is the ash content of the moisture free biomass sample.

Ash content $(\%, \mathrm{~d} . \mathrm{b})=\frac{W 3-W 1}{W 2-W 1}$

Where, $\mathrm{W}_{1}=$ weight of empty crucible $(\mathrm{g})$

$\mathrm{W}_{2}=$ Initial weight of the sample plus crucible (g)

$\mathrm{W}_{3}=$ Final weight of sample (ash) plus crucible $(\mathrm{g})$

\section{Fixed carbon}

The fixed carbon represents the non-volatile combustible component of the fuel. After determining fuel moisture content (d.b.), volatile matter (d.b.) and fuel ash content (d.b.), the fixed carbon content is estimated from the material balance equation given below:

$\mathrm{FC}(\%$ d.b. $)=100-\mathrm{VM}(\%$ d.b. $)-\mathrm{ASH}$ (\%d.b.)

Where,

FC $(\%$ d.b. $)=$ Percentage of fixed carbon on dry basis

VM $(\%$ d.b. $)=$ Percentage of volatile matter on dry basis

ASH $(\%$ d.b. $)=$ Percentage of ash on dry basis

\section{Results and Discussion}

Physical and thermal properties of rice husk, rice straw, sugarcane bagasse and cotton stalks

Different physical properties and thermal properties of various agricultural residues viz. moisture content, bulk density, true density, porosity, angle of repose, volatile matter, ash content and fixed carbon was measured using standard methods as shown in Tab. 1.

For each sample three replications were taken. Its average was taken to prepare result that shown in Table. 1. Bulk density of rice husk and rice straw was $331.59 \mathrm{~kg} / \mathrm{m}^{3}$ and 380.54 $\mathrm{kg} / \mathrm{m}^{3}$ respectively. For sugarcane bagasse and cotton stalk it was 723.2 and $206.14 \mathrm{~kg} / \mathrm{m}^{3}$ respectively. True density determined as per Eq. 2, its value found for rice husk, rice straw, sugarcane bagasse and cotton stalk was 1031.7, 1671.97, 4594.66 and $507.36 \mathrm{~kg} / \mathrm{m}^{3}$ respectively.

As shown in Eq. 3 porosity for rice husk, rice straw, sugarcane bagasse and cotton stalk was calculated as 67.86, 77.24, 84.26 and 59.37 per cent respectively. Angle of repose found with cone method and it was recorded as 
$37.04,38.23,43.24$ and 43.18 degree for rice husk, rice straw, sugarcane bagasse and cotton stalk respectively. In powder form cotton stalk and sugarcane bagasse followed nearly same texture that's why difference between their angle of repose is prettyminor. Here, moister content was taken into account for all these Moister content recorded for rice husk and rice straw was 7.52 and $9.89 \%$ d.b. respectively and for sugarcane bagasse and cotton stalk as 11.11 and $10.01 \%$ d.b. respectively.

Table.1 Physical and thermal properties of various agricultural residues

\begin{tabular}{|c|c|c|c|c|}
\hline Properties & Rice husk & Rice straw & $\begin{array}{c}\text { Sugarcane } \\
\text { bagasse }\end{array}$ & Cotton stalk \\
\hline $\begin{array}{c}\text { Bulk density, } \\
\text { kg/m }\end{array}$ & 331.59 & 380.54 & 723.2 & 206.14 \\
\hline $\begin{array}{c}\text { True density, } \\
\text { kg/m }\end{array}$ & 1031.71 & 1671.97 & 4594.66 & 507.36 \\
\hline Porosity, & 67.86 & 77.24 & 84.26 & 59.37 \\
\hline Angle of repose, & 37.04 & 38.23 & 43.24 & 43.18 \\
\hline Moisture content & 7.52 & 9.89 & 11.11 & 10.01 \\
\hline Volatile matter & 70.70 & 64.43 & 86.15 & 96.07 \\
\hline Ash content & 18.60 & 15.20 & 3.28 & 6.93 \\
\hline Fixed carbon & 10.7 & 20.37 & 10.62 & 10.7 \\
\hline
\end{tabular}

As like above physical properties, thermal properties were also determined for all these agricultural residues. Such as volatile matter and ash content were also estimated. By this estimation its potential for thermal use can be determined. Volatile matter and ash content for rice husk, rice straw, sugarcane bagasse and cotton stalk was recorded as 70.70, 64.43, 86.15, $96.07 \%$ d.b. and 18.60, 15.20, 3.28, $6.93 \%$ d.b. respectively. By putting these values of volatile matter and ash content in Eq. 7 and 8. fixed carbon for residues was determined as 10.7, 20.37, 10.62 and 10.7 for rice husk, rice straw, sugarcane bagasse and cotton stalk respectively.

These various engineering properties helps significantly for designing of equipment, enhance production of plant, developing new technologies in which agricultural residues are used as raw material. Physical property is important to get idea about its storage, transportation, etc. whereas thermal properties provide information about its energy output potential. Burning of crop residue not only leads to pollution but also results in loss of nutrients present in the residues. Hence the use of agricultural residues as bio fuel provides optimum option for farmers to handle it. Thermal properties become useful for each and every step for determining fuel potential from agricultural residues.

\section{References}

AOAC. (1999). Official Methods of Analysis, Association of Official Analytical Chemists. Washington DC, USA.

AOAC. (2000). Official Methods of Analysis, Association of Official Analytical Chemists. Washington DC, USA.

ASTM E870-82, 2013. "Standard Test Methods for Analysis of Wood Fuels", ASTM International, West Conshohocken, PA, 2013, www.astm.org

Gagandeep Kaur Sidhu* and Sandhya (2015). Engineering properties of cotton stalks 
(Gossypium hirsitum L.) Indian J. Agric. Res., 49 (5) 2015: 456-459.

Murali S, Shrivastava R, Saxena M. (2007) "Quantification of agricultural residues for energy generation - a casestudy". J Inst Public Health Eng 2008; 200708(3): 27.

Murali S., Shrivastava R., Morchhale R. (2015) "Agricultural Residue-Based Power Generation: A Viable Option in India. In: Reddy B., Ulgiati S. (eds) Energy Security and Development Springer", New Delhi.393-409

Prasad S, Singh A, Joshi HC. (2007) "Ethanol as an alternative fuel from agricultural, industrial and urban residues".
ResourConservRecycl 2007; 50(2007): 1-39.

Ravindranath NH, Hall DO (1995). "Biomass energy and environment". Oxford: Oxford University Press; 1995.

Stegner, W. (1972). Angle of Repose by Penguin Twentieth-Century Classics.

Yaning Zhang, A.E. Ghaly and Bingxi Li (2012). "Availability and physical properties of residues from major agricultural crops for energy conversio through thermochemical processes" American Journal of Agricultural and Biological Science, 2012, 7 (3), 312321.

\section{How to cite this article:}

Makavana, J.M., V.V. Agravat, P.R. Balas, P.J. Makwana and Vyas, V.G. 2018. Engineering Properties of Various Agricultural Residue. Int.J.Curr.Microbiol.App.Sci. 7(06): 2362-2367. doi: https://doi.org/10.20546/ijcmas.2018.706.282 